\title{
Microstructure, Mechanical Properties and Fracture Behavior of As-Extruded Zn-Mg Binary Alloys
}

\author{
Li-Qing Wang ${ }^{1} \cdot$ Yu-Ping Ren ${ }^{1} \cdot$ Shi-Neng Sun ${ }^{1} \cdot$ Hong Zhao ${ }^{1} \cdot{\text { Song } \mathrm{Li}^{1} \cdot \text { Gao-Wu Qin }}^{1}$
}

Received: 11 January 2017/Revised: 27 February 2017/Published online: 26 April 2017

(C) The Chinese Society for Metals and Springer-Verlag Berlin Heidelberg 2017

\begin{abstract}
In the present work, $\mathrm{Zn}-(0-1) \mathrm{Mg}$ (wt\%) alloys were prepared by casting and indirect extrusion at 200 and $300{ }^{\circ} \mathrm{C}$, respectively. With $\mathrm{Mg}$ addition, both the size and amount of second phase $\mathrm{Mg}_{2} \mathrm{Zn}_{11}$ increased, and the equiaxed grains were significantly refined. The extrusion temperature had little influence on $\mathrm{Mg}_{2} \mathrm{Zn}_{11}$, but the grains were refined at low extrusion temperature. For the alloys extruded at $200{ }^{\circ} \mathrm{C}$, as $\mathrm{Mg}$ content increased, the tensile yield strength (TYS) increased from $64 \mathrm{MPa}$ for pure $\mathrm{Zn}$ to $262 \mathrm{MPa}$ for $\mathrm{Zn}-1 \mathrm{Mg}$; the elongation increased from $14.3 \%$ for pure $\mathrm{Zn}$ to $25 \%$ for $\mathrm{Zn}-0.02 \mathrm{Mg}$ and then decreased to $5 \%$ for $\mathrm{Zn}-1 \mathrm{Mg}$. For the alloys extruded at $300{ }^{\circ} \mathrm{C}$, as $\mathrm{Mg}$ content increased, the TYS increased from $67 \mathrm{MPa}$ for pure $\mathrm{Zn}$ to $252 \mathrm{MPa}$ for $\mathrm{Zn}-1 \mathrm{Mg}$, while the elongation decreased from $11.7 \%$ to $2 \%$. The alloy extruded at $200{ }^{\circ} \mathrm{C}$ exhibited higher TYS and elongation than the corresponding alloy extruded at $300{ }^{\circ} \mathrm{C}$. The combination of grain refinement and second phase $\mathrm{Mg}_{2} \mathrm{Zn}_{11}$ contributed to the improvement in the TYS, and the grain refinement played a major role in strengthening alloy. $\mathrm{Zn}-0.02 \mathrm{Mg}$ and $\mathrm{Zn}-0.05 \mathrm{Mg}$ alloys extruded at $200{ }^{\circ} \mathrm{C}$ show a mixture of cleavage and ductile fracture corresponding to higher elongation, while the other alloys show cleavage fracture.
\end{abstract}

\section{KEY WORDS: Zn-Mg binary alloy; Indirect extrusion; Microstructure; Mechanical property; Fracture behavior}

\section{Introduction}

Zinc ( $\mathrm{Zn})$ is an essential trace element and plays important roles in various aspects of basic biological function in human body [1, 2]. Besides, $\mathrm{Zn}$ with a standard electrode potential of $-0.8 \mathrm{~V}$ is between that of $\mathrm{Mg}(-2.4 \mathrm{~V})$ and $\mathrm{Fe}$ $(-0.4 \mathrm{~V})[3,4]$, which provides its moderate degradability.

Available online at http://link.springer.com/journal/40195.

Yu-Ping Ren

renyp@atm.neu.edu.cn

$\triangle$ Gao-Wu Qin

qingw@smm.neu.edu.cn

1 Key Laboratory for Anisotropy and Texture of Materials (Ministry of Education), School of Materials Science and Engineering, Northeastern University, Shenyang 110819, China
As $\mathrm{Zn}$ has a low melting point of $420{ }^{\circ} \mathrm{C}$ and low reactivity in molten state, it favors an easy manufacture. Therefore, it has attracted much attention to develop new biodegradable $\mathrm{Zn}$-based materials in recent years. Bowen et al. [5] implanted pure $\mathrm{Zn}$ wires into the abdominal aorta of adult male Sprague-Dawley rats. It indicated that the in vivo degradation rate increased linearly from 10 to $50 \mu \mathrm{m} /$ year within 6 months. Vojtech et al. [6] studied the in vitro degradation rates of the as-cast $\mathrm{Zn}-(0-3) \mathrm{Mg}$ alloys (wt\%, all of the contents refer to weight percentage if not specifically stated). The results showed that the degradation rates of $\mathrm{Zn}-\mathrm{Mg}$ alloys were much lower than those of $\mathrm{Mg}$ alloys, indicating that Zn-based alloys could be potential candidates for biodegradable material.

However, pure $\mathrm{Zn}$ and the as-cast $\mathrm{Zn}-\mathrm{Mg}$ alloys were difficult to satisfy the mechanical properties requirement of the implant materials. Recently, new binary and ternary Zn-based alloys containing $\mathrm{Mg}, \mathrm{Ca}, \mathrm{Sr}$ and $\mathrm{Mn}$ were 
achieved by hot extrusion and rolling [3, 6-14]. These Znbased alloys exhibited good biocompatibility, appropriate degradation rate and significantly improved mechanical properties. Till now, most of the work focused on the biocompatibility, while the influence of the microstructure on the mechanical properties of the Zn-based alloys has rarely been studied. The mechanical properties of pure $\mathrm{Zn}$ are strongly dependent on the extrusion process. The tensile yield strength (TYS), ultimate tensile strength (UTS) and elongation reached $35 \mathrm{MPa}, 65 \mathrm{MPa}$ and $4 \%$ for pure $\mathrm{Zn}$ extruded at $210^{\circ} \mathrm{C}[12,13], 55 \mathrm{MPa}, 100 \mathrm{MPa}$ and $7.5 \%$ for pure $\mathrm{Zn}$ extruded at $300{ }^{\circ} \mathrm{C}$ [7], and $130 \mathrm{MPa}$, $180 \mathrm{MPa}$ and $54 \%$ for pure $\mathrm{Zn}$ extruded at $200{ }^{\circ} \mathrm{C}$ [11]. The reasons for such large differences in mechanical properties are not clearly stated and might be ascribed to grain size and texture caused by the different extrusion processes. Furthermore, the $\mathrm{Zn}-0.8 \mathrm{Mg}$ alloy [7] extruded at $300{ }^{\circ} \mathrm{C}$ showed TYS, UTS and elongation of $203 \mathrm{MPa}$, $301 \mathrm{MPa}$ and $15 \%$, respectively. The microstructure analysis showed that it was composed of $\mathrm{Mg}_{2} \mathrm{Zn}_{11}, \mathrm{MgZn}_{2}$ and equiaxed grains with a size of $12 \mu \mathrm{m}$, while the TYS and UTS of $\mathrm{Zn}-1.6 \mathrm{Mg}$ alloy [7] were higher, but the elongation significantly decreased to about $4 \%$ due to the only second phase $\mathrm{Mg}_{2} \mathrm{Zn}_{11}$ distributed as continuous network. Gong et al. [11] reported that the $\mathrm{Zn}-1 \mathrm{Mg}$ alloy extruded at $200{ }^{\circ} \mathrm{C}$ exhibited TYS, UTS and elongation of $180 \mathrm{MPa}$, $250 \mathrm{MPa}$ and $12 \%$, respectively. The as-extruded $\mathrm{Zn}-1 \mathrm{Mg}$ alloy contained the grains with size of $5 \mu \mathrm{m}$ and fine precipitates segregated along grain boundaries. So the low extrusion temperature was beneficial to grain refinement, and precipitation of the second phase played important role in improving mechanical properties. Li et al. [12, 13] prepared $\mathrm{Zn}-1 X$ and $\mathrm{Zn}-1 X-1 Y(X, Y=\mathrm{Mg}, \mathrm{Ca}, \mathrm{Sr})$ alloys by hot rolling and hot extrusion. The TYS, UTS and elongation of the Zn-based alloys were between 140-220 MPa, 200-260 MPa and 5-20\%, respectively. The binary and ternary Zn-based alloys contained one or two kinds of second phases among $\mathrm{MgZn}_{2}, \mathrm{CaZn}_{13}$ and $\mathrm{SrZn}_{13}$. The as-rolled $\mathrm{Zn}-1 \mathrm{Mg}-0.1 \mathrm{Mn}$ alloy [8] containing the only second phase $\mathrm{MgZn}_{2}$ exhibited TYS, UTS and elongation values of $195 \mathrm{MPa}, 300 \mathrm{MPa}$ and $26 \%$, respectively, while the as-rolled $\mathrm{Zn}-1 \mathrm{Mg}-0.1 \mathrm{Sr}$ alloy [9] containing second phases $\mathrm{MgZn}_{2}$ and $\mathrm{SrZn}_{13}$ exhibited TYS, UTS and elongation values of $197 \mathrm{MPa}, 300 \mathrm{MPa}$ and $22 \%$. However, the mechanical properties of the $\mathrm{Zn}$ based alloys have not been well understood due to the lack of the microstructural characterization.

Therefore, for the $\mathrm{Zn}-\mathrm{Mg}$-based alloys, both the alloying element content and manufacturing history had influence on the microstructures, in turn, the mechanical properties. In the present work, $\mathrm{Zn}-(0-1) \mathrm{Mg}$ alloys were selected according to $\mathrm{Zn}-\mathrm{Mg}$ phase diagram [15] for extrusion at 200 and $300{ }^{\circ} \mathrm{C}$, respectively. The microstructure, mechanical properties and fracture behavior of the as-extruded $\mathrm{Zn}-\mathrm{Mg}$ alloys were studied, and it will provide reference for designing and preparation of biodegradable $\mathrm{Zn}$-based alloys.

\section{Materials and Methods}

Pure $\mathrm{Zn}$ and $\mathrm{Zn}-(0.02-1) \mathrm{Mg}$ binary alloys were prepared by melting pure $\mathrm{Zn}(99.95 \mathrm{wt} \%)$ and $\mathrm{Mg}(99.95 \mathrm{wt} \%)$ in a resistance furnace in air. The melting temperature did not exceed $500{ }^{\circ} \mathrm{C}$ for preventing excessive evaporation of the volatile zinc. Cylindrical ingots $(\Phi 60 \mathrm{~mm})$ were obtained by casting into a non-preheated steel mold. After the homogenization treatment at $330{ }^{\circ} \mathrm{C}$ for $4 \mathrm{~h}$, the ingots were machined to billets for extrusion $(\Phi 48 \times 100 \mathrm{~mm})$. Then, the indirect extrusion was carried out at 200 and $300{ }^{\circ} \mathrm{C}$, respectively, with an extrusion ratio of $16: 1$, ram speed of about $3 \mathrm{~mm} / \mathrm{s}$. The cylindrical rods of $12 \mathrm{~mm}$ in diameter were obtained. Finally the extruded rods were cooled in air. The actual composition of the investigated $\mathrm{Zn}-\mathrm{Mg}$ binary alloys was determined by an inductively coupled plasma atomic emission spectrometer (ICP-AES, Optima 4300DV, PE, USA), which is given in Table 1.

The microstructure of the as-extruded alloys was investigated by optical microscopy (OM) (OLYMPUS GX71), scanning electron microscopy (SEM) (JEOL JSM6510A) and X-ray diffraction (XRD) (Philips PW3040/60). Samples parallel to the extrusion direction were taken from the extrudate. They were ground up to 2000 grit by $\mathrm{SiC}$ paper, followed by mechanically polishing with $0.5 \mu \mathrm{m}$ diamond pastes. Samples for OM were etched for 3-10 s in a solution of $10 \%$ hydrochloric acid and $90 \%$ alcohol and then washed immediately using alcohol. Grain size was measured using the linear intercept method on the OM images. The second phase was analyzed by XRD with $\mathrm{Cu}-$ $K \alpha$ radiation and scan rate of $3 \%$ min.

Mechanical properties were characterized by tensile test. Tensile specimens with $5 \mathrm{~mm}$ in diameter and gauge length of $25 \mathrm{~mm}$ were machined from the extruded rods. The tensile test was carried out at a constant cross-head speed of $1.5 \mathrm{~mm} / \mathrm{min}$ at room temperature. Three samples were tested for each alloy. Then, TYS, UTS and elongation of all

Table $1 \mathrm{Mg}$ content of the as-extruded $\mathrm{Zn}-\mathrm{Mg}$ binary alloys (wt\%)

\begin{tabular}{ll}
\hline Alloys & $\mathrm{Mg}$ \\
\hline $\mathrm{Zn}-0.02 \mathrm{Mg}$ & 0.024 \\
$\mathrm{Zn}-0.05 \mathrm{Mg}$ & 0.056 \\
$\mathrm{Zn}-0.2 \mathrm{Mg}$ & 0.216 \\
$\mathrm{Zn}-0.5 \mathrm{Mg}$ & 0.464 \\
$\mathrm{Zn}-1 \mathrm{Mg}$ & 0.975 \\
\hline
\end{tabular}


the alloys were determined. The fracture surface after tensile tests was observed by SEM.

\section{Results}

\subsection{Microstructure}

Figure 1 shows the optical micrographs of $\mathrm{Zn}-(0-1) \mathrm{Mg}$ alloys extruded at 200 and $300{ }^{\circ} \mathrm{C}$. The as-extruded $\mathrm{Zn}-\mathrm{Mg}$ alloys exhibited equiaxed grains, and the twins were observed in the as-extruded $\mathrm{Zn}-(0-1) \mathrm{Mg}$ alloys. During the hot extrusion process, the $\mathrm{Zn}$ matrix experienced fully dynamic recrystallization, and the grain size significantly decreased with increasing $\mathrm{Mg}$ content, as shown in Fig. 2. As $\mathrm{Mg}$ content increased from 0 to $0.2 \mathrm{wt} \%$, the grain size decreased from 112 to $16 \mu \mathrm{m}$ after the alloys were extruded at $200{ }^{\circ} \mathrm{C}$, and the grain size decreased from 203 to $38 \mu \mathrm{m}$ after extruded at $300{ }^{\circ} \mathrm{C}$. It is apparent that the grain size of the alloys extruded at $200{ }^{\circ} \mathrm{C}$ was about half of that of the alloys extruded at $300{ }^{\circ} \mathrm{C}$, meaning that the lower extrusion temperature favored the grain refinement of the $\mathrm{Zn}-(0-0.2) \mathrm{Mg}$ alloys. However, for $\mathrm{Zn}-0.5 \mathrm{Mg}$ and $\mathrm{Zn}-$ $1 \mathrm{Mg}$, the grain size kept at about $10 \mu \mathrm{m}$, and the extrusion temperature had little influence on the grain size.

The back-scattered electron (SEM-BSE) images of the as-extruded $\mathrm{Zn}-(0.02-1) \mathrm{Mg}$ alloys are shown in Fig. 3 . Evidently only one kind of second phase was found in these alloys. Meanwhile, the XRD patterns of $\mathrm{Zn}-1 \mathrm{Mg}$ extruded at 200 and $300{ }^{\circ} \mathrm{C}$ confirmed that the second phase was $\mathrm{Mg}_{2} \mathrm{Zn}_{11}$ as shown in Fig. 4. The amount and size of $\mathrm{Mg}_{2} \mathrm{Zn}_{11}$ increased with an increase in $\mathrm{Mg}$ content and showed little difference in the alloy extruded at different temperatures. $\mathrm{Mg}_{2} \mathrm{Zn}_{11}$ particles formed in $\mathrm{Zn}-$ $0.02 \mathrm{Mg}$ with an average size of $0.5 \mu \mathrm{m}$ and reached between 0.4 and $2 \mu \mathrm{m}$ in size corresponding to the average size of $0.8 \mu \mathrm{m}$ in $\mathrm{Zn}-0.05 \mathrm{Mg}$. When $\mathrm{Mg}$ content was more than $0.2 \mathrm{wt} \%, \mathrm{Mg}_{2} \mathrm{Zn}_{11}$ distributed along the grain boundaries as shown in Fig. 1 and gradually transformed into strip shaped and distributed parallel to the extrusion direction. In $\mathrm{Zn}-1 \mathrm{Mg}$ alloy, the length of the strip $\mathrm{Mg}_{2} \mathrm{Zn}_{11}$ elongated to $20 \mu \mathrm{m}$ which was larger than the matrix grain size, and also some small $\mathrm{Mg}_{2} \mathrm{Zn}_{11}$ particles about $1 \mu \mathrm{m}$ in size were observed.

\subsection{Mechanical Properties}

Figure $5 \mathrm{a}, \mathrm{b}$ shows the room temperature engineering stress-strain curves of the $\mathrm{Zn}-\mathrm{Mg}$ alloys extruded at 200 and $300{ }^{\circ} \mathrm{C}$, respectively. For $\mathrm{Zn}-0.02 \mathrm{Mg}$ extruded at $200{ }^{\circ} \mathrm{C}$ and $\mathrm{Zn}-0.02 \mathrm{Mg}$ and $\mathrm{Zn}-0.05 \mathrm{Mg}$ extruded at $300{ }^{\circ} \mathrm{C}$, obvious serrated flow behavior on the curves occurred after yielding of the alloys. This phenomenon was related to the nucleation of deformation twins during tensile process [16].

The mechanical properties including TYS, UTS and elongation are summarized in Fig. 5c, d. Firstly, both the TYS and UTS continuously increased as Mg content increased. After the extrusion at $200{ }^{\circ} \mathrm{C}$, TYS and UTS were 64 and $110 \mathrm{MPa}$ for pure $\mathrm{Zn}$ and were improved to 262 and $330 \mathrm{MPa}$ for $\mathrm{Zn}-1 \mathrm{Mg}$, while extruded at $300{ }^{\circ} \mathrm{C}$, TYS and UTS were 67 and $109 \mathrm{MPa}$ for pure $\mathrm{Zn}$ and were also improved to 253 and $323 \mathrm{MPa}$ for $\mathrm{Zn}-1 \mathrm{Mg}$. The TYS and UTS of pure $\mathrm{Zn}$ showed less independence on the extrusion temperatures. However, $\mathrm{Zn}-(0.02-1) \mathrm{Mg}$ alloys extruded at $200{ }^{\circ} \mathrm{C}$ possessed higher TYS and UTS than $\mathrm{Zn}-(0.02-1) \mathrm{Mg}$ alloys extruded at $300{ }^{\circ} \mathrm{C}$. Therefore, according to the variations of the microstructures mentioned above, the strength of the as-extruded $\mathrm{Zn}-\mathrm{Mg}$ alloys is generally dominated by the combinations of solid solution strengthening, grain refinement and precipitation strengthening. Secondly, after the extrusion at $200^{\circ} \mathrm{C}$, the elongation increased from $14.3 \%$ for pure $\mathrm{Zn}$ to $25 \%$ for $\mathrm{Zn}-0.02 \mathrm{Mg}$, then decreased when $\mathrm{Mg}$ content exceeded $0.02 \mathrm{wt} \%$ and finally reached about $5 \%$ for $\mathrm{Zn}-1 \mathrm{Mg}$. But the elongation of $\mathrm{Zn}-(0-1) \mathrm{Mg}$ alloys extruded at $300{ }^{\circ} \mathrm{C}$ showed different trend, and it continuously decreased from $11.7 \%$ to about $2 \%$ as $\mathrm{Mg}$ content increased. Meanwhile, it showed that $\mathrm{Zn}-(0-1) \mathrm{Mg}$ alloys extruded at $200{ }^{\circ} \mathrm{C}$ exhibited improved ductility compared with the same alloy extruded at $300{ }^{\circ} \mathrm{C}$.

\subsection{Fracture Behavior}

To verify the fracture mechanisms and their relations with the mechanical properties, the fracture surface was observed and is shown in Figs. 6 and 7. It is seen that $\mathrm{Zn}-0.02 \mathrm{Mg}$ and $\mathrm{Zn}-0.05 \mathrm{Mg}$ extruded at $200{ }^{\circ} \mathrm{C}$ exhibited quite different morphologies from the other alloys. Except $\mathrm{Zn}-0.02 \mathrm{Mg}$ and $\mathrm{Zn}-0.05 \mathrm{Mg}$ extruded at $200{ }^{\circ} \mathrm{C}$, the other $\mathrm{Zn}$ alloys showed characteristic of brittle fracture. It could be observed intragranular cracks, cleavage steps and cleavage planes surrounded by tearing ridges in pure $\mathrm{Zn}$, which indicated typical cleavage fracture mode. But as $\mathrm{Mg}$ content increased, the size of cleavage planes decreased. Meanwhile, with increasing $\mathrm{Mg}_{2} \mathrm{Zn}_{11}$ amount and size, the fracture between the $\mathrm{Zn}$ matrix and $\mathrm{Mg}_{2} \mathrm{Zn}_{11}$ happened more frequently, and the area of tearing ridges reduced and even disappeared, which resulted in the gradual reduction in elongation.

The fracture surface of $\mathrm{Zn}-0.02 \mathrm{Mg}$ and $\mathrm{Zn}-0.05 \mathrm{Mg}$ extruded at $200{ }^{\circ} \mathrm{C}$ is shown in Fig. $6 c$, e and d, f, respectively. It could be observed obvious tear lip in morphology at low magnification. However, at high magnification, the fractures consisted of cleavage planes, tearing ridges and some dimples. It meant that both alloys showed a mixture of cleavage and ductile fracture modes 

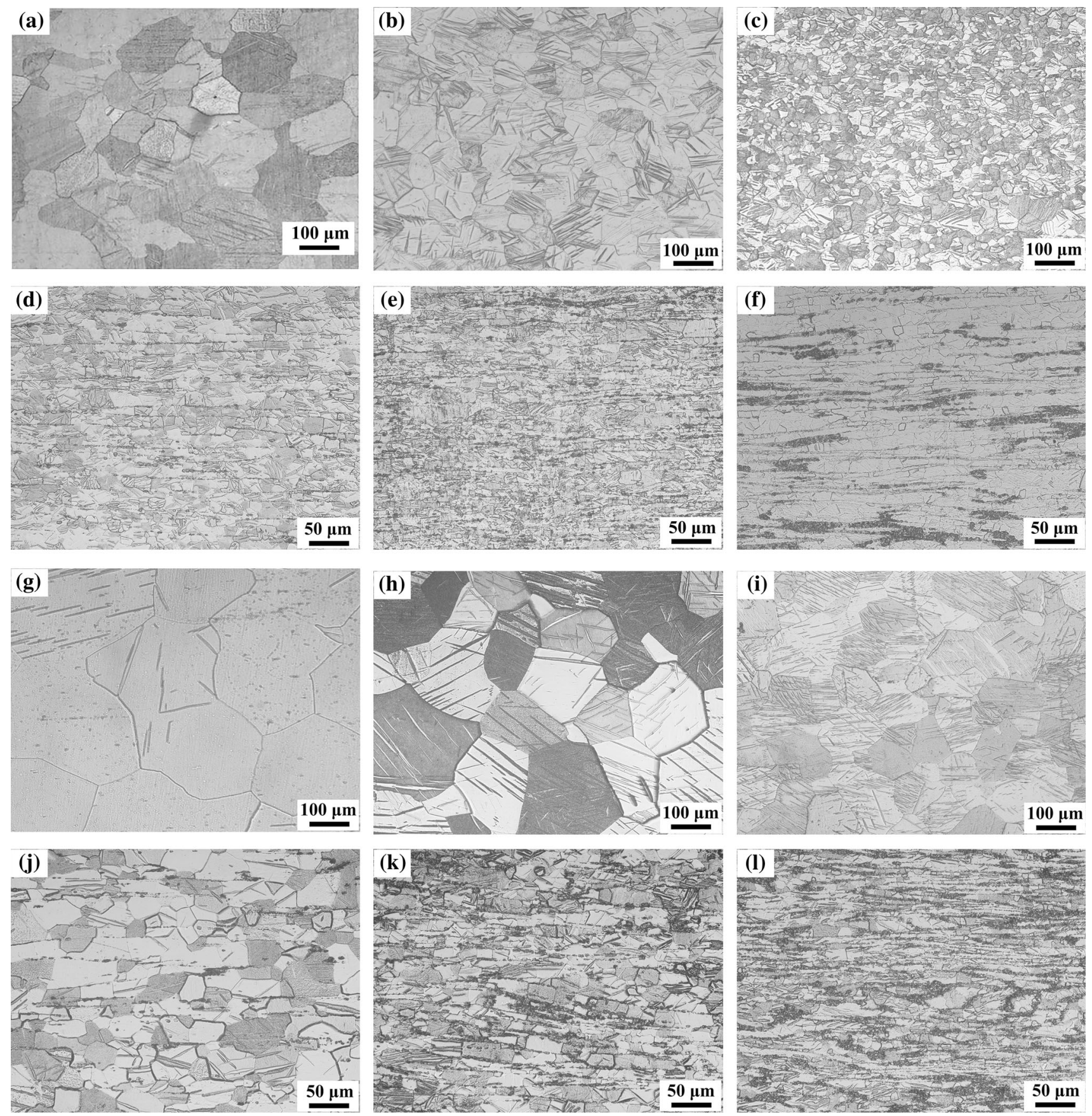

Extruded Direction

Fig. 1 Optical micrographs of the $\mathrm{Zn}-\mathrm{Mg}$ binary alloys on longitudinal section: a pure $\mathrm{Zn}$ at $200{ }^{\circ} \mathrm{C}, \mathbf{b} \mathrm{Zn}-0.02 \mathrm{Mg}$ at $200{ }^{\circ} \mathrm{C}$, $\mathbf{c} \mathrm{Zn}-0.05 \mathrm{Mg}$ at $200{ }^{\circ} \mathrm{C}, \mathbf{d ~ Z n}-0.2 \mathrm{Mg}$ at $200{ }^{\circ} \mathrm{C}$, e $\mathrm{Zn}-0.5 \mathrm{Mg}$ at $200{ }^{\circ} \mathrm{C}$, f Zn- $1 \mathrm{Mg}$ at $200{ }^{\circ} \mathrm{C}$, g pure $\mathrm{Zn}$ at $300{ }^{\circ} \mathrm{C}, \mathbf{h ~ Z n}-0.02 \mathrm{Mg}$ at $300{ }^{\circ} \mathrm{C}, \mathbf{i} \mathrm{Zn}-0.05 \mathrm{Mg}$ at $300{ }^{\circ} \mathrm{C}, \mathbf{j} \mathrm{Zn}-0.2 \mathrm{Mg}$ at $300{ }^{\circ} \mathrm{C}, \mathbf{k} \mathrm{Zn}-0.5 \mathrm{Mg}$ at $300{ }^{\circ} \mathrm{C}, \mathbf{l} \mathrm{Zn}-1 \mathrm{Mg}$ at $300{ }^{\circ} \mathrm{C}$

and corresponded to larger elongation of 25 and $13.6 \%$, respectively. The ductile fracture was determined by the size of the dimples which were originated from microvoids aggregation, while the formation of the microvoids and resultant dimples were attributed to fracture of $\mathrm{Mg}_{2} \mathrm{Zn}_{11}$ particles and $\mathrm{Zn}$ matrix. On the other hand, when comparing the other $\mathrm{Zn}$ alloys with $\mathrm{Zn}-0.02 \mathrm{Mg}$ or $\mathrm{Zn}-$ $0.05 \mathrm{Mg}$ extruded at $200{ }^{\circ} \mathrm{C}$ containing similar $\mathrm{Mg}_{2} \mathrm{Zn}_{11}$ particles or grain size, the brittle cleavage fracture to ductile fracture transition was in relation to proper matching of the size and volume fraction of $\mathrm{Mg}_{2} \mathrm{Zn}_{11}$ particle and grain size. 


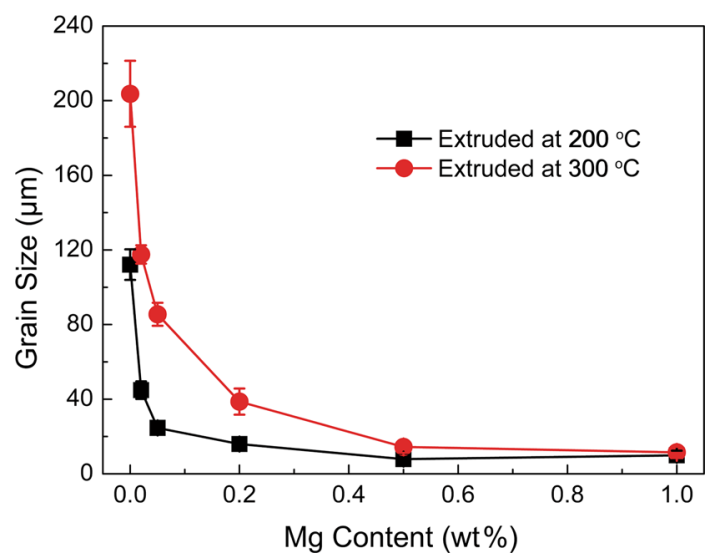

Fig. 2 Variation of the average grain size of the $\mathrm{Zn}-\mathrm{Mg}$ binary alloys with $\mathrm{Mg}$ content

\section{Discussion}

\subsection{Microstructure}

In the present work, the $\mathrm{Zn}-(0-1) \mathrm{Mg}$ alloys were prepared by indirect extrusion at 200 and $300{ }^{\circ} \mathrm{C}$. During the hot extrusion process, $\mathrm{Mg}_{2} \mathrm{Zn}_{11}$ compound was broken up and arranged along the extrusion direction; meanwhile, the equiaxed grains of $\mathrm{Zn}$ matrix formed during dynamic recrystallization. The size of the recrystallized grains was primarily influenced by extrusion temperature and hinderance of $\mathrm{Mg}_{2} \mathrm{Zn}_{11}$, finally leading to the variation of grain sizes in Fig. 2. For pure $\mathrm{Zn}$, the grain size was reduced by $50 \%$ as the extrusion temperature decreased from 300 to $200{ }^{\circ} \mathrm{C}$. Usually lower extrusion temperature reduced the grain boundary migration rate [17] and finally resulted in the grain refinement. For $\mathrm{Zn}-(0.02-1) \mathrm{Mg}$ alloys, except for the effect of extrusion temperature, $\mathrm{Mg}_{2} \mathrm{Zn}_{11}$ particles played an important role in the grain refinement by not only serving as the crystal nucleus to facilitate the nucleation of recrystallization, but also pinning grain boundary to retard the grain growth. The effect of the particles on the grain refinement can be expressed by Zener pinning pressure $\left(P_{\mathrm{Z}}\right)[17,18]:$

$P_{\mathrm{Z}}=\frac{3 f_{\mathrm{S} \gamma}}{2 r}$

where $f_{\mathrm{S}}$ and $r$ are the second phase volume fraction and radius, respectively, and $\gamma$ is grain boundary interfacial energy. It means that alloy with greater $P_{\mathrm{Z}}$ would exhibit smaller grain size. In the present work, as $\mathrm{Mg}$ content increased from 0 to $0.2 \mathrm{wt} \%$, the increase in $f_{\mathrm{S}}$ was greater than that in $r$, and it resulted in the increase in $P_{\mathrm{Z}}$. So the grain size decreased significantly with $\mathrm{Mg}$ addition. On the other hand, the grain sizes of $\mathrm{Zn}-(0.02-0.2) \mathrm{Mg}$ alloys extruded at $200{ }^{\circ} \mathrm{C}$ were less than half of those extruded at
$300{ }^{\circ} \mathrm{C}$, which meant that the extrusion temperature still had obvious effect on the grain refinement. However, when $\mathrm{Mg}$ content reached 0.5 and $1 \mathrm{wt} \%$, the increase in $f_{\mathrm{S}}$ was almost equal to the increase in $r$. So the grain size of these alloys was not further refined and kept at about $10 \mu \mathrm{m}$. Besides, the extrusion temperature had very slightly influence on the grain refinement for $\mathrm{Zn}-0.5 \mathrm{Mg}$ and $\mathrm{Zn}-$ $1 \mathrm{Mg}$. Furthermore, according to Eq. (1), the grain size still was potential further to refined by reducing the size of $\mathrm{Mg}_{2} \mathrm{Zn}_{11}$, especially for $\mathrm{Zn}-0.5 \mathrm{Mg}$ and $\mathrm{Zn}-1 \mathrm{Mg}$.

\subsection{Mechanical properties}

As for the relationship between the microstructure and mechanical properties of the as-extruded $\mathrm{Zn}-(0-1) \mathrm{Mg}$ alloys, the strengthening mechanism models for TYS can be divided into solid solution strengthening, $\Delta \sigma_{\mathrm{SS}}$; grain boundary strengthening, $\Delta \sigma_{\mathrm{g}}$; and second phase strengthening, $\Delta \sigma_{\mathrm{S}}$. Therefore, TYS $\left(\sigma_{\mathrm{y}}\right)$ of the $\mathrm{Zn}-\mathrm{Mg}$ alloys can be approximated as:

$\sigma_{\mathrm{y}}=\sigma_{0}+\Delta \sigma_{\mathrm{SS}}+\Delta \sigma_{\mathrm{g}}+\Delta \sigma_{\mathrm{S}}$

where $\sigma_{0}$ is the intrinsic resistance of the lattice to dislocation motion. Each of the strengthening mechanisms for the $\mathrm{Zn}-\mathrm{Mg}$ alloys is discussed as follows.

(1) Solid solution strengthening depends on the solute concentration of $\mathrm{Mg}$ in $\mathrm{Zn}$ matrix and can be expressed as:

$\Delta \sigma_{\mathrm{SS}}=k \times c^{n}$,

where $k$ is the strengthening constant in solute, $c$ is the atomic concentration of solute, $n$ is a constant and usually taken as $1 / 2$ or $2 / 3$ [19-21]. Liu et al. [22] pointed out that the contribution of solid solution strengthening for $0.03 \mathrm{wt} \% \mathrm{Mg}$ dissolved in $\mathrm{Zn}$ matrix was about $12 \mathrm{MPa}$. However, in the present $\mathrm{Zn}-(0-1) \mathrm{Mg}$ alloys, $\mathrm{Mg}_{2} \mathrm{Zn}_{11}$ particles precipitated in $\mathrm{Zn}-0.02 \mathrm{Mg}$, and both the volume fraction and size of $\mathrm{Mg}_{2} \mathrm{Zn}_{11}$ increased with increasing $\mathrm{Mg}$ content. Therefore, the concentration of $\mathrm{Mg}$ dissolved in Zn matrix could not exceed $0.02 \mathrm{wt} \%$ (i.e., 0.0054 at.\%). So it is regarded that the contribution of solid solution strengthening to TYS could be neglected.

(2) The grain boundary strengthening is calculated according to Hall-Petch relationship [19-21] as follows:

$\Delta \sigma_{\mathrm{g}}=k_{\mathrm{H}-\mathrm{P}} \times d_{\mathrm{g}}^{-1 / 2}$,

where $k_{\mathrm{H}-\mathrm{P}}$ is the Hall-Petch constant and $d_{\mathrm{g}}$ is the grain size. In the present work, $\sigma_{0}=32.3 \mathrm{MPa}$ and $k_{\mathrm{H}-\mathrm{P}}=220 \mathrm{MPa} \mu \mathrm{m}^{1 / 2}$ [23] were adopted for pure $\mathrm{Zn}$, while $\sigma_{0}=11 \mathrm{MPa}$ and $k_{\mathrm{H}-\mathrm{P}}=580 \mathrm{MPa} \mu \mathrm{m}^{1 / 2}$ [22] were adopted for $\mathrm{Zn}-(0.02-1) \mathrm{Mg}$ alloys. The contributions of grain boundary strengthening to TYS of the as-extruded $\mathrm{Zn}-(0-1) \mathrm{Mg}$ alloys are listed in Tables 2 and 3. 

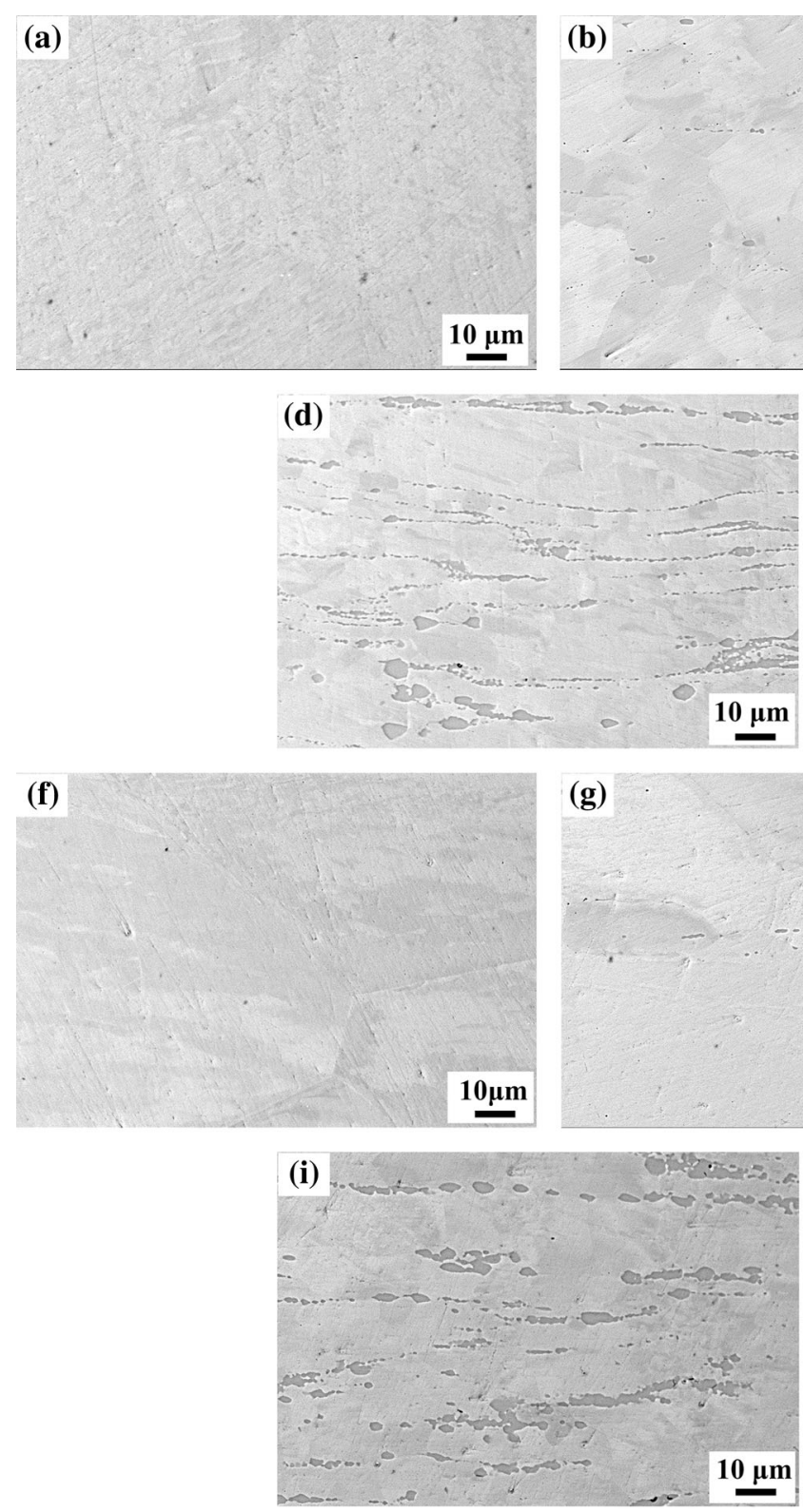

Extruded Direction (b)

(g)

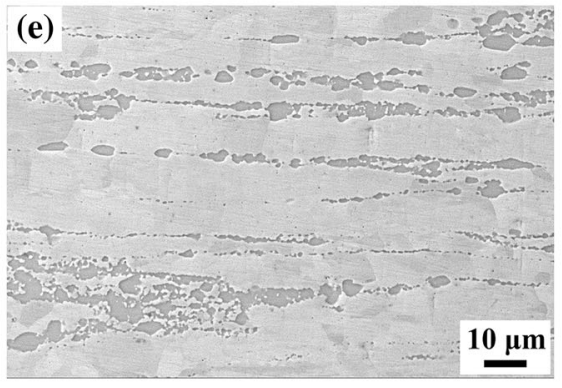

(h)

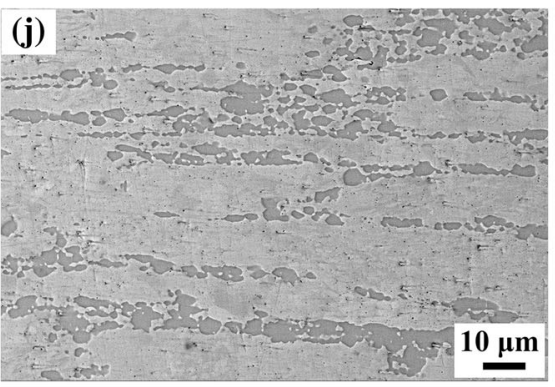

$10 \mu \mathrm{m}$ (c)

$10 \mu \mathrm{m}$

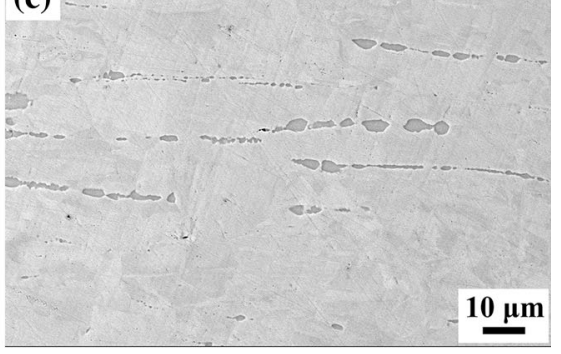

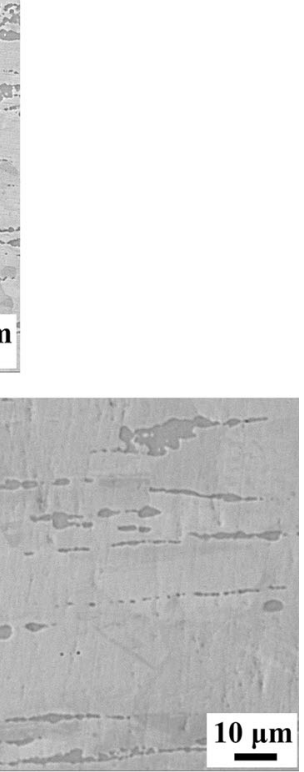

بm

Fig. 3 SEM-BSE morphologies of the $\mathrm{Zn}-\mathrm{Mg}$ binary alloys on longitudinal section: a $\mathrm{Zn}-0.02 \mathrm{Mg}$ at $200{ }^{\circ} \mathrm{C}$, b $\mathrm{Zn}-0.05 \mathrm{Mg}$ at $200{ }^{\circ} \mathrm{C}$, $\mathbf{c} \mathrm{Zn}-$ $0.2 \mathrm{Mg}$ at $200{ }^{\circ} \mathrm{C}, \mathbf{d ~ Z n}-0.5 \mathrm{Mg}$ at $200{ }^{\circ} \mathrm{C}, \mathbf{e ~ Z n}-1 \mathrm{Mg}$ at $200{ }^{\circ} \mathrm{C}, \mathbf{f ~ Z n}-0.02 \mathrm{Mg}$ at $300{ }^{\circ} \mathrm{C}, \mathbf{g ~ Z n}-0.05 \mathrm{Mg}$ at $300{ }^{\circ} \mathrm{C}, \mathbf{h} \mathrm{Zn}-0.2 \mathrm{Mg}$ at $300{ }^{\circ} \mathrm{C}, \mathbf{i} \mathrm{Zn}-$ $0.5 \mathrm{Mg}$ at $300{ }^{\circ} \mathrm{C}, \mathbf{j} \mathrm{Zn}-1 \mathrm{Mg}$ at $300{ }^{\circ} \mathrm{C}$

(3) Second phase strengthening originates from the different properties between the second phase and matrix and depends on the morphology, volume fraction and size of second phase. In the present work, $\mathrm{Zn}-0.02 \mathrm{Mg}$ and $\mathrm{Zn}-$ $0.05 \mathrm{Mg}$ alloys contained small $\mathrm{Mg}_{2} \mathrm{Zn}_{11}$ particles distributing along the grain boundaries. Thus, the strengthening mechanism can be classified into load transfer from $\mathrm{Zn}$ matrix to $\mathrm{Mg}_{2} \mathrm{Zn}_{11}, \Delta \sigma_{\mathrm{LT}}$; dislocation generation due to the difference in thermal expansion between $\mathrm{Zn}$ matrix and $\mathrm{Mg}_{2} \mathrm{Zn}_{11}, \Delta \sigma_{\mathrm{CET}}$; and dislocation-particle interaction by
Orowan process, $\Delta \sigma_{\mathrm{OR}}[19,24]$. Then, second phase strengthening can be expressed in the following equation:

$$
\begin{aligned}
\Delta \sigma_{\mathrm{S}}= & \Delta \sigma_{\mathrm{LT}}+\Delta \sigma_{\mathrm{CTE}}+\Delta \sigma_{\mathrm{OR}} \\
= & \frac{1}{2} \sigma_{\mathrm{M}} f_{\mathrm{S}}+\alpha G b\left(\frac{12 \cdot \Delta T \cdot \Delta C \cdot f_{\mathrm{S}}}{b \cdot d_{\mathrm{S}}}\right)^{1 / 2} \\
& +M \frac{0.81 G b}{2 \pi \sqrt{1-v}}\left(0.615 d_{\mathrm{S}} \sqrt{\frac{2 \pi}{3 f_{\mathrm{S}}}}-d_{\mathrm{S}}\right)^{-1} \ln \frac{d_{\mathrm{S}}}{b},
\end{aligned}
$$




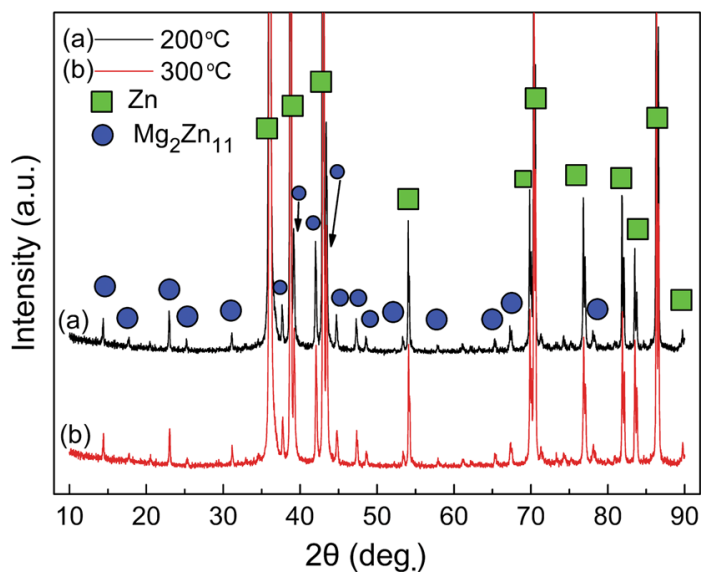

Fig. $4 \mathrm{X}$-ray diffraction patterns of the $\mathrm{Zn}-1 \mathrm{Mg}$ alloys extruded at 200 and $300{ }^{\circ} \mathrm{C}$

where $\sigma_{\mathrm{M}}$ is the TYS of $\mathrm{Zn}$ matrix, $f_{\mathrm{S}}$ is the volume fraction of $\mathrm{Mg}_{2} \mathrm{Zn}_{11}$ particles, $\alpha$ is a constant taken as $1, G$ is the shear modulus of $\mathrm{Zn}$ matrix $(=43 \mathrm{GPa}), b$ is the Burgers vector $(=0.2664 \mathrm{~nm}), \Delta T$ is the temperature change between the extrusion and tensile testing, $\Delta C$ is the difference in thermal expansion coefficient between $\mathrm{Zn}$
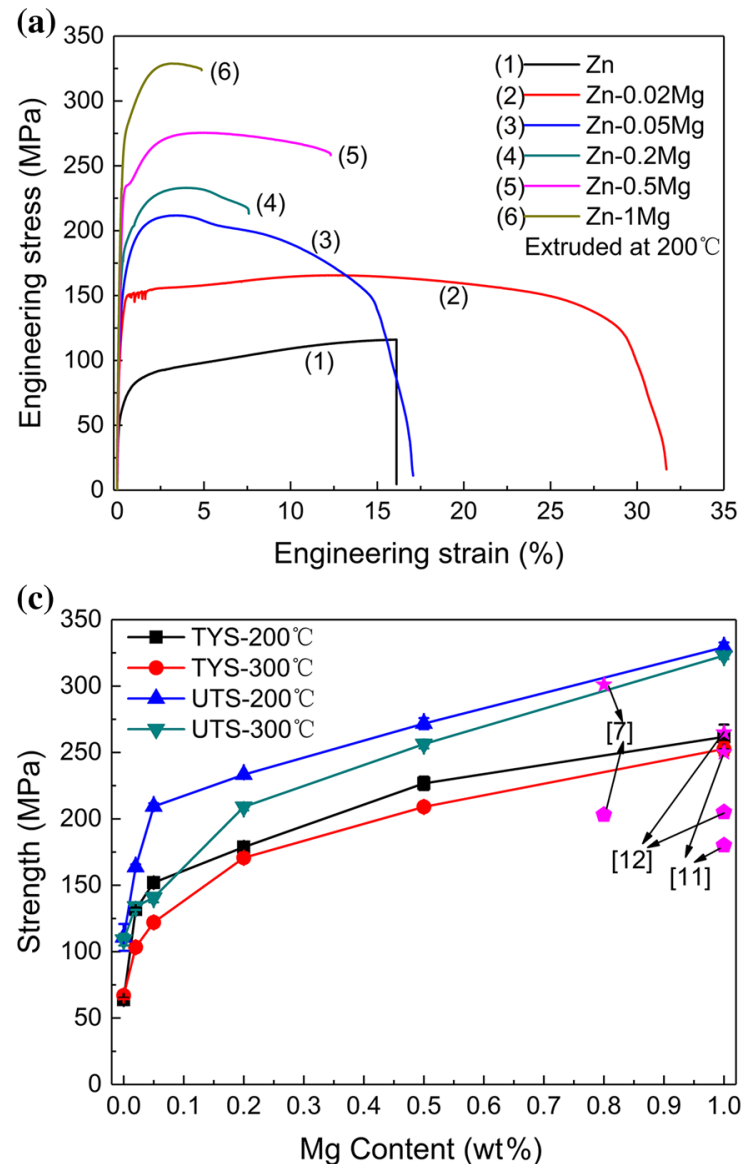

$\left(C_{\mathrm{Zn}}=30.2 \times 10^{-6} \mathrm{~K}^{-1}\right)$ and $\mathrm{Mg}_{2} \mathrm{Zn}_{11}\left(C_{\mathrm{Mg} 2 \mathrm{Zn} 11}\right.$ has not been obtained), so $\Delta C=0-30.2 \times 10^{-6} \mathrm{~K}^{-1}, d_{\mathrm{S}}$ is the mean diameter of $\mathrm{Mg}_{2} \mathrm{Zn}_{11}, M$ is the Taylor factor $(=6.5$ $[19,23]), v$ is the Poisson's ratio $(=0.25)$.

When $\mathrm{Mg}$ content reached $0.2,0.5$ and $1 \mathrm{wt} \%$, the size of $\mathrm{Mg}_{2} \mathrm{Zn}_{11}$ obviously increased; moreover, it was also larger than that of $\mathrm{Zn}$ grains. So the strengthening effect by interaction between dislocations and particles was no longer adapted. In this case, the discontinuous strip-shaped $\mathrm{Mg}_{2} \mathrm{Zn}_{11}$ would act as discontinuous fibers to undertake load. Therefore, the law of mixtures in discontinuous fiber composite materials can be introduced to these $\mathrm{Zn}-\mathrm{Mg}$ alloys and given as [25]:

$\sigma_{\mathrm{y}}=\sigma_{\mathrm{M}}\left(1-f_{\mathrm{S}}\right)+\lambda \sigma_{\mathrm{S}} f_{\mathrm{S}}$

where $\sigma_{\mathrm{y}}$ is TYS of $\mathrm{Zn}-\mathrm{Mg}$ alloy, $\sigma_{\mathrm{S}}$ is TYS of $\mathrm{Mg}_{2} \mathrm{Zn}_{11}, \lambda$ is correction coefficient and can be expressed as:

$\lambda=\frac{L}{2 l_{\mathrm{c}}}$,

where $L$ is the length of $\mathrm{Mg}_{2} \mathrm{Zn}_{11}, l_{\mathrm{c}}$ is the critical length of $\mathrm{Mg}_{2} \mathrm{Zn}_{11}$ : when $L>l_{\mathrm{c}}$, the invalidation of $\mathrm{Zn}-\mathrm{Mg}$ alloy is caused by the fracture of $\mathrm{Mg}_{2} \mathrm{Zn}_{11}$; when $L<l_{\mathrm{c}}$, the
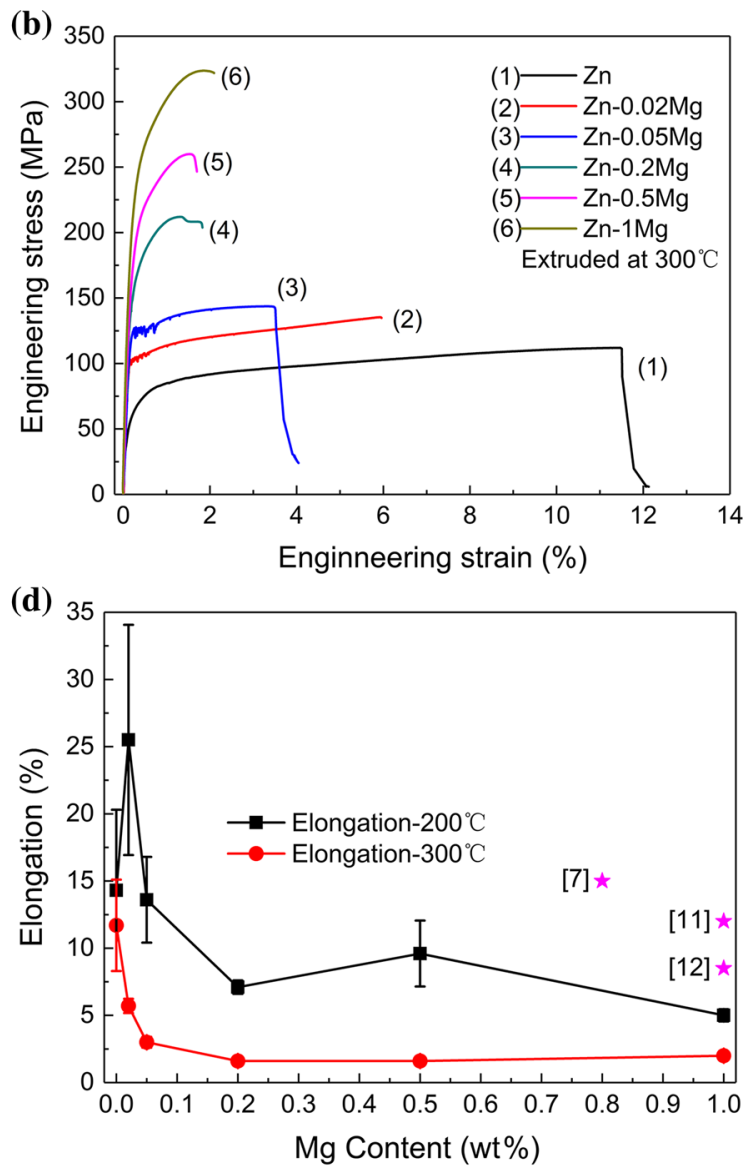

Fig. 5 Tensile stress-strain curves of the $\mathrm{Zn}-\mathrm{Mg}$ binary alloys extruded at a $200{ }^{\circ} \mathrm{C}, \mathbf{b} 300{ }^{\circ} \mathrm{C}$. Tensile properties of the as-extruded $\mathrm{Zn}-\mathrm{Mg}$ binary alloys: $\mathbf{c}$ strength and $\mathbf{d}$ elongation 

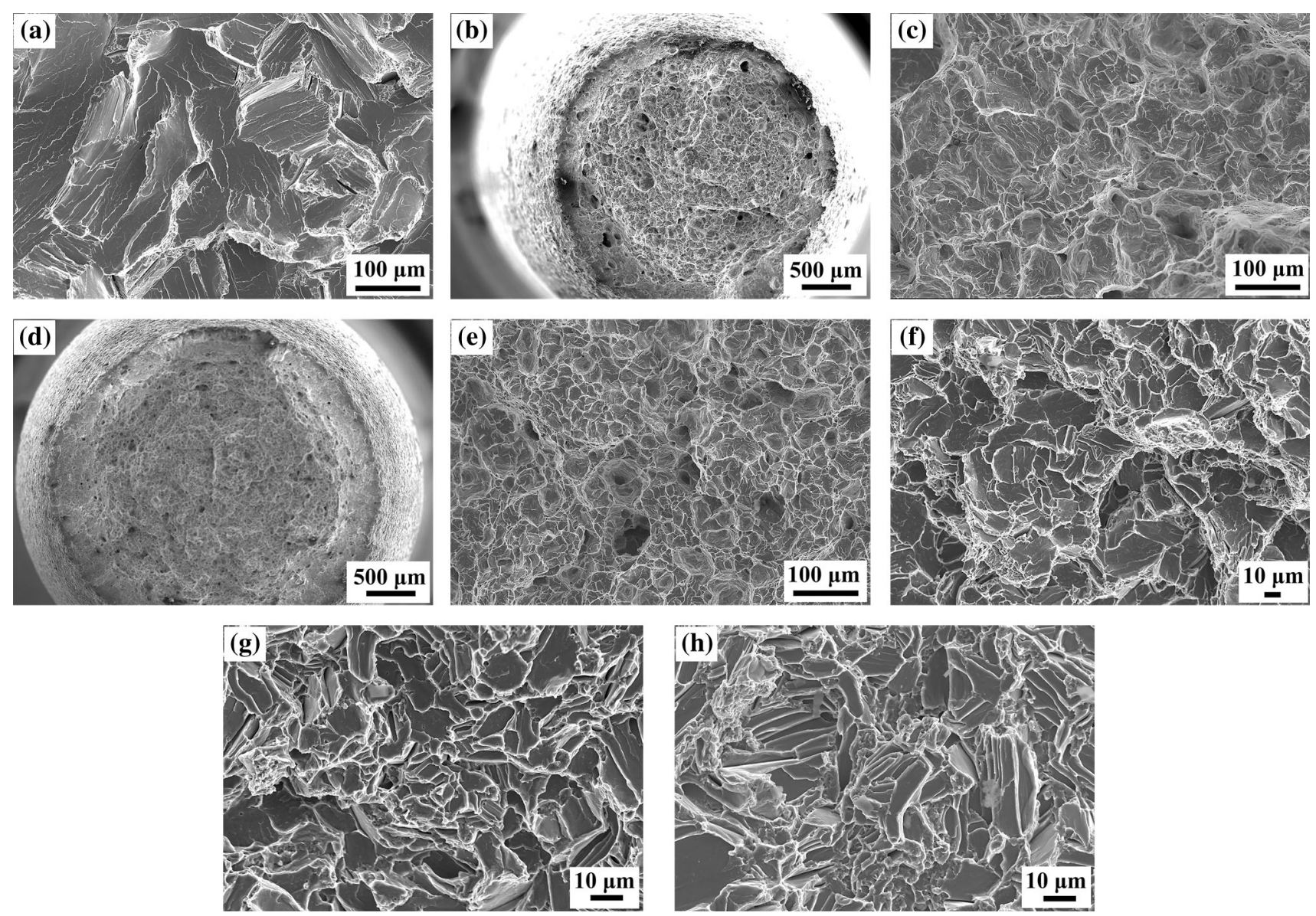

Fig. 6 Fracture morphologies of the $\mathrm{Zn}-\mathrm{Mg}$ binary alloys extruded at $200{ }^{\circ} \mathrm{C}$ : $\mathbf{a} \mathrm{Zn}, \mathbf{b}$, $\mathbf{c}$ low and high magnification of $\mathrm{Zn}-0.02 \mathrm{Mg}$, d, e low and high magnification of $\mathrm{Zn}-0.05 \mathrm{Mg}, \mathbf{f} \mathrm{Zn}-0.2 \mathrm{Mg}, \mathbf{g} \mathrm{Zn}-0.5 \mathrm{Mg}$, h $\mathrm{Zn}-1 \mathrm{Mg}$
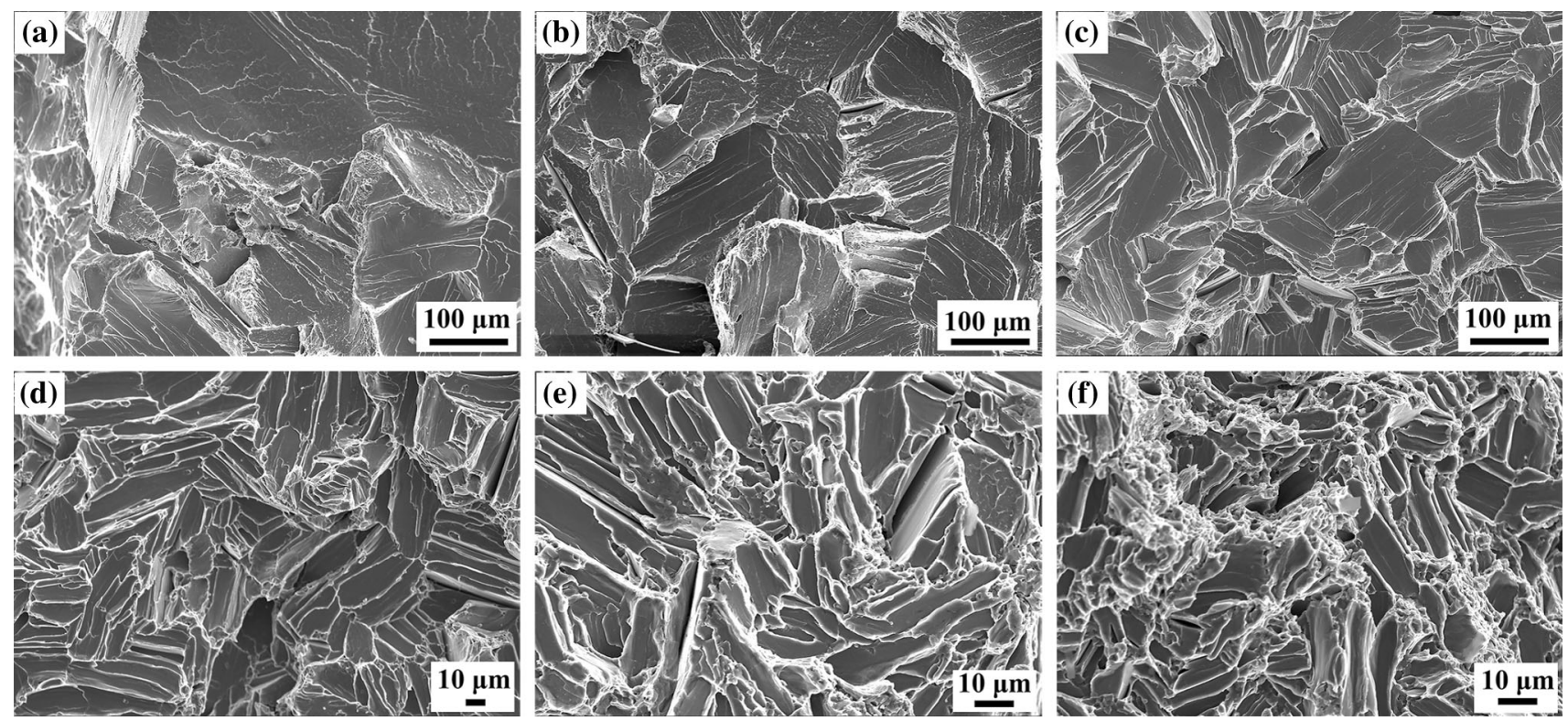

Fig. 7 Fracture morphologies of the $\mathrm{Zn}-\mathrm{Mg}$ binary alloys extruded at $300{ }^{\circ} \mathrm{C}$ : a $\mathrm{Zn}, \mathbf{b} \mathrm{Zn}-0.02 \mathrm{Mg}, \mathbf{c} \mathrm{Zn}-0.05 \mathrm{Mg}, \mathbf{d} \mathrm{Zn}-0.2 \mathrm{Mg}$, e $\mathrm{Zn}-0.5 \mathrm{Mg}$, f $\mathrm{Zn}-1 \mathrm{Mg}$ 
Table 2 Respective contributions of the strengthening mechanisms to the $\mathrm{Zn}-\mathrm{Mg}$ binary alloys extruded at $200{ }^{\circ} \mathrm{C}$

\begin{tabular}{|c|c|c|c|c|c|c|}
\hline Alloys (wt\%) & $\mathrm{Zn}$ & $\mathrm{Zn}-0.02 \mathrm{Mg}$ & $\mathrm{Zn}-0.05 \mathrm{Mg}$ & $\mathrm{Zn}-0.2 \mathrm{Mg}$ & $\mathrm{Zn}-0.5 \mathrm{Mg}$ & $\mathrm{Zn}-1 \mathrm{Mg}$ \\
\hline$d_{\mathrm{g}}(\mu \mathrm{m})$ & 112 & 45 & 24 & 16 & 9 & 9 \\
\hline$d_{\mathrm{S}}(\mu \mathrm{m})$ & & 0.5 & 0.8 & & & \\
\hline$f_{\mathrm{S}}$ & & 0.0037 & 0.0092 & 0.037 & 0.092 & 0.183 \\
\hline$\sigma_{0}(\mathrm{MPa})$ & 32.3 & 11 & & & & \\
\hline$\Delta \sigma_{\mathrm{g}}(\mathrm{MPa})$ & 20.8 & 86.5 & 118.4 & 145 & 193.3 & 193.3 \\
\hline$\Delta \sigma_{\mathrm{S}}(\mathrm{MPa})$ & - & $12.4-27.9$ & $14.0-33.2$ & - & - & - \\
\hline Calculated $\sigma_{\mathrm{y}}(\mathrm{MPa})$ & 53.1 & $109.9-125.4$ & $143.4-162.6$ & 170.6 & 236.1 & 267.6 \\
\hline Tested $\sigma_{\mathrm{y}}(\mathrm{MPa})$ & 64 & 132 & 152 & 179 & 227 & 262 \\
\hline
\end{tabular}

Table 3 Respective contributions of the strengthening mechanisms to the $\mathrm{Zn}-\mathrm{Mg}$ binary alloys extruded at $300{ }^{\circ} \mathrm{C}$

\begin{tabular}{|c|c|c|c|c|c|c|}
\hline Alloys (wt\%) & $\mathrm{Zn}$ & $\mathrm{Zn}-0.02 \mathrm{Mg}$ & $\mathrm{Zn}-0.05 \mathrm{Mg}$ & $\mathrm{Zn}-0.2 \mathrm{Mg}$ & $\mathrm{Zn}-0.5 \mathrm{Mg}$ & $\mathrm{Zn}-1 \mathrm{Mg}$ \\
\hline$d_{\mathrm{g}}(\mu \mathrm{m})$ & 203 & 117 & 85 & 38 & 14 & 11 \\
\hline$d_{\mathrm{S}}(\mu \mathrm{m})$ & & 0.5 & 0.8 & & & \\
\hline$f_{\mathrm{S}}$ & & 0.0037 & 0.0092 & 0.037 & 0.092 & 0.183 \\
\hline$\sigma_{0}(\mathrm{MPa})$ & 32.3 & 11 & & & & \\
\hline$\Delta \sigma_{\mathrm{g}}(\mathrm{MPa})$ & 15.4 & 53.6 & 62.9 & 94.1 & 155.0 & 174.9 \\
\hline$\Delta \sigma_{\mathrm{S}}(\mathrm{MPa})$ & - & $12.4-31.6$ & $13.7-37.7$ & - & - & - \\
\hline Calculated $\sigma_{\mathrm{y}}(\mathrm{MPa})$ & 47.7 & $77.0-96.2$ & $87.6-111.6$ & 121.6 & 201.3 & 252.5 \\
\hline Tested $\sigma_{\mathrm{y}}(\mathrm{MPa})$ & 67 & 103 & 122 & 170 & 209 & 252 \\
\hline
\end{tabular}

invalidation of $\mathrm{Zn}-\mathrm{Mg}$ alloy is caused by the fracture between $\mathrm{Mg}_{2} \mathrm{Zn}_{11}$ and $\mathrm{Zn}$ matrix. Then, $\lambda$ is simplified as 0.5 . For the TYS of $\mathrm{Mg}_{2} \mathrm{Zn}_{11}\left(\sigma_{\mathrm{S}}\right)$, typical load-displacement curve of $\mathrm{Mg}_{2} \mathrm{Zn}_{11}$ was tested by nanoindentation [26], and it showed that the hardness of $\mathrm{Mg}_{2} \mathrm{Zn}_{11}$ was $3.76 \mathrm{GPa}$; then, $\sigma_{\mathrm{S}}$ was calculated between 1.0 and $1.2 \mathrm{GPa}$ using the method provided by Serban et al. [27]. Here, $\sigma_{\mathrm{S}}$ is taken as the average value of $1.1 \mathrm{GPa}$.

The volume fraction of the precipitate can be given as $[21,28]$ :

$f_{\mathrm{S}}=\frac{x \Omega^{\mathrm{P}}}{x \Omega^{P}+(1-x) \Omega^{\mathrm{m}}}$,

where $\Omega^{\mathrm{P}}$ and $\Omega^{\mathrm{m}}$ are the average atomic volumes of the precipitate and matrix and $x$ is the atomic fraction of the precipitate. $\mathrm{Mg}_{2} \mathrm{Zn}_{11}$ is cubic structure with $a=0.8552 \mathrm{~nm}$, containing 39 atoms per unit cell (PDF\#65-1853), while $\mathrm{Zn}$ is hexagonal structure with $a=0.2665 \mathrm{~nm}$ and $c=0.4947 \mathrm{~nm}$, containing two atoms per unit cell (PDF\#65-5973), so $\Omega^{\mathrm{P}}=16.0 \times 10^{-3} \mathrm{~nm}^{3}$ and $\Omega^{\mathrm{m}}=15.2 \times 10^{-3} \mathrm{~nm}^{3}$. Then, Eq. (8) simplifies as $f_{\mathrm{S}}=\frac{16 x}{15.2-0.8 x}$.

In this work, the contribution of solid solution strengthening to TYS could be neglected due to the relative low solubility. Then, TYS of matrix $\left(\sigma_{\mathrm{M}}\right)$ can be expressed as $\sigma_{\mathrm{M}}=\sigma_{0}+\Delta \sigma_{\mathrm{g}}$. Relevant parameters and calculated results of strengthening mechanism of the as-extruded $\mathrm{Zn}-$
(0-1)Mg alloys are shown in Tables 2 and 3. Firstly, TYS of pure $\mathrm{Zn}$ was only dominated by the grain size. The grain size of $\mathrm{Zn}$ extruded at $200{ }^{\circ} \mathrm{C}$ was about half of that extruded at $300{ }^{\circ} \mathrm{C}$, but both of them had similar calculated TYS which was in agreement with the experimental results. Secondly, TYS of $\mathrm{Zn}-(0.02-1) \mathrm{Mg}$ alloys originates from the grain boundary strengthening and second phase strengthening. According to the calculation results, the contribution of grain boundary strengthening increases with $\mathrm{Mg}$ addition and accounts for more than $50 \%$, and even it reaches $80 \%$ in the alloys extruded at $200{ }^{\circ} \mathrm{C}$. Therefore, the grain boundary strengthening becomes the main strengthening mechanism. The contribution of second phase strengthening increases with $\mathrm{Mg}$ addition, even though it has different mechanisms depending on the morphology of $\mathrm{Mg}_{2} \mathrm{Zn}_{11}$. Finally, from the calculated results of the $\mathrm{Zn}-\mathrm{Mg}$ alloy extruded at 200 and $300{ }^{\circ} \mathrm{C}$, it indicates that the grain refinement primarily results in the higher TYS of the alloy extruded at $200{ }^{\circ} \mathrm{C}$.

In addition, the mechanical properties of $\mathrm{Zn}-\mathrm{Mg}$ alloys in Refs. [7, 11, 12] are shown in Fig. 5c, d and were compared with the present work. It indicated that the $\mathrm{Zn}-$ $0.8 / 1 \mathrm{Mg}$ alloys [7, 11, 12] exhibited lower strength and higher elongation than the alloy in this work. The difference in the mechanical properties of these alloys was caused by the microstructures including grain size, kinds and size of second phase. Both of $\mathrm{Zn}-0.8 \mathrm{Mg}$ [7] and $\mathrm{Zn}-$ $1 \mathrm{Mg}$ in the present work contained grains about $10 \mu \mathrm{m}$ in 
size. But the large-sized $\mathrm{Mg}_{2} \mathrm{Zn}_{11}$ in the present $\mathrm{Zn}-1 \mathrm{Mg}$ has more significant strengthening effect than small-sized $\mathrm{Mg}_{2} \mathrm{Zn}_{11}$ or $\mathrm{MgZn}_{2}$ in $\mathrm{Zn}-0.8 \mathrm{Mg}$ [7]. And the $\mathrm{Zn}-\mathrm{Mg}$ alloys with refined grains and/or second phase exhibited the improvement in elongation. The microstructure of the alloy depends on composition of alloying elements and preparation history. According to the results in the present work, the grain size strongly depends on extrusion temperature and volume fraction and size of $\mathrm{Mg}_{2} \mathrm{Zn}_{11}$, while it is known that extrusion temperature has little influence on morphology of $\mathrm{Mg}_{2} \mathrm{Zn}_{11}$. So apart from the deformation process, it is essential to control the solidification process for adjusting the morphology of $\mathrm{Mg}_{2} \mathrm{Zn}_{11}$ in the future work.

\section{Conclusions}

In this study, $\mathrm{Zn}-(0-1) \mathrm{Mg}$ alloys were prepared by indirect extrusion with extrusion ratio of $16: 1$ at 200 and $300{ }^{\circ} \mathrm{C}$, respectively. The microstructure, mechanical properties and fracture behavior were investigated, and the possible strengthening mechanisms were analyzed. The following conclusions were obtained:

In the $\mathrm{Zn}-\mathrm{Mg}$ binary alloys, $\mathrm{Mg}$ addition induced the formation of $\mathrm{Mg}_{2} \mathrm{Zn}_{11}$, and the morphology of $\mathrm{Mg}_{2} \mathrm{Zn}_{11}$ had no difference in the alloy extruded at 200 and $300{ }^{\circ} \mathrm{C}$. The grain refinement was achieved by increasing $\mathrm{Mg}$ content and/or decreasing extrusion temperature.

Both TYS and UTS of the as-extruded $\mathrm{Zn}-\mathrm{Mg}$ alloys continuously increased with increasing $\mathrm{Mg}$ content, and they also increased at lower extrusion temperature. The $\mathrm{Zn}-\mathrm{Mg}$ alloys were mainly strengthened by grain boundary strengthening and second phase strengthening, and grain boundary strengthening was in dominance.

$\mathrm{Zn}-0.02 \mathrm{Mg}$ and $\mathrm{Zn}-0.05 \mathrm{Mg}$ extruded at $200{ }^{\circ} \mathrm{C}$ exhibited a mixture of cleavage and ductile fracture mode, corresponding to higher elongation. The other alloys showed typically cleavage fracture, and the elongation decreased with increasing $\mathrm{Mg}$ content. Meanwhile, the alloy extruded at $200{ }^{\circ} \mathrm{C}$ showed a higher elongation than that extruded at $300{ }^{\circ} \mathrm{C}$.

Acknowledgements This work was supported by the National Natural Science Foundation of China (Nos. 51525101 and 51371046), the Program for New Century Excellent Talents in University (No. NECT-12-0109) and the Fundamental Research Funds for the Central Universities (Nos. N130510002, N141008001).

\section{References}

[1] R. Hansch, R.R. Mendel, Curr. Opin. Plant Biol. 129, 259 (2009)

[2] L. Rink, Zn in Human Health (IOS Press, Amsterdam, 2011)

[3] D. Vojtech, J. Kubasek, J. Capek, I. Pospisilova, Mater. Technol. 49, 877 (2015)

[4] D.E. Talbot, J.D. Talbot, Corrosion Science and Technology (CRC Press, Boca Raton, 2007)

[5] P.K. Bowen, J. Drelich, J. Goldman, Adv. Mater. 25, 2577 (2013)

[6] D. Vojtech, J. Kubásek, J. Šerák, P. Novák, Acta Biomater. 7, 3515 (2011)

[7] J. Kubasek, D. Vojtech, E. Jablonska, I. Pospisilova, J. Lipov, T. Ruml, Mater. Sci. Eng., C 58, 24 (2016)

[8] X.W. Liu, J.K. Sun, F.Y. Zhou, Y.H. Yang, R.C. Chang, K.J. Qiu, Z.J. Pu, L. Li, Y.F. Zheng, Mater. Des. 94, 95 (2016)

[9] X.W. Liu, J.K. Sun, Y.H. Yang, F.Y. Zhou, Z.J. Pu, L. Li, Y.F. Zheng, Mater. Lett. 165, 242 (2016)

[10] J. Kubasek, I. Pospisilova, D. Vojtech, E. Jablonska, T. Ruml, Mater. Technol. 48, 623 (2014)

[11] H. Gong, K. Wang, R. Strich, J.G. Zhou, J. Biomed. Mater. Res. B 103, 1632 (2015)

[12] H.F. Li, H.X. Xie, Y.F. Zheng, Y. Cong, F.Y. Zhou, K.J. Qiu, X. Wang, S.H. Chen, L. Huang, L. Tian, L. Qin, Sci. Rep. 5, 10719 (2015)

[13] H.F. Li, H.T. Yang, Y.F. Zheng, F.Y. Zhou, K.J. Qiu, X. Wang, Mater. Des. 83, 95 (2015)

[14] N.S. Murni, M.S. Dambatta, S.K. Yeap, G.R.A. Froemming, H. Hermawan, Mater. Sci. Eng., C 49, 560 (2015)

[15] P. Ghosh, M. Mezbahul-Islam, M. Medraj, CALPHAD 36, 28 (2012)

[16] J.H. Liu, C.X. Huang, S.D. Wu, Z.F. Zhang, Mater. Sci. Eng., A 409, 117 (2008)

[17] F.J. Humphreys, M. Hatherly, Recrystallization and Related Annealing Phenomena, 2nd edn. (Elsevier Science, New York, 2004)

[18] N.G. Ross, M.R. Barnet, A.G. Beer, Mater. Sci. Eng., A 619, 238 (2014)

[19] B.Q. Shi, R.S. Chen, W. Ke, J. Alloys Compd. 509, 3357 (2011)

[20] L. Cao, R.S. Chen, E.H. Han, J. Alloys Compd. 472, 234 (2009)

[21] Y. Chen, N. Gao, G. Sha, S.P. Ringer, M.J. Starink, Acta Mater. 109, 202 (2016)

[22] Z.L. Liu, D. Qiu, F. Wang, J.A. Taylor, M.X. Zhang, Metall. Mater. Trans. A 47, 830 (2016)

[23] R. Armstrong, I. Codd, R.M. Douthwaite, N.J. Petch, Philos. Mag. 7, 45 (1962)

[24] M. Mabuchi, K. Higashi, Acta Mater. 44, 4611 (1996)

[25] J.W. Liu, X.D. Peng, M.L. Li, G.B. Wei, W.D. Xie, Y. Yang, Mater. Sci. Eng., A 655, 331 (2016)

[26] C.C. Kammerer, S. Behdad, L. Zhou, F. Betancor, M. Gonzales, B. Boesl, Y.H. Sohn, Intermetallics 67, 145 (2015)

[27] V.A. Serban, C. Codrean, M. Voda, D. Chicot, X. Decoopman, Mater. Sci. Eng., A 605, 294 (2014)

[28] A. Deschamps, A. Bigot, F.L. Vet, P. Auger, Y. Brechet, D. Blavette, Philos. Mag. A 81, 2391 (2001) 